Dursun, F./ Sosyal Bilimler Araştırmaları Dergisi. 2, (2006):33-57

\title{
Birleştirilmiş Sınıflarda Eğitim Sorunları ve Çözüm Önerileri
}

\section{Fevzi Dursun ${ }^{a}$}

\begin{abstract}
Özet
Bu çalışmanın hedefi Türkiye'deki ilköğretim okullarında uygulanan birleştirilmiş sınıflarda öğretim uygulamasında karşılaşılan sorunları saptayarak; bu uygulamada görev alan öğretmen ve mesleğe ilerde başlayacak olan öğretmen adayı öğrencilerin görüş ve çözüm önerilerini belirlemek ve karşılaştırmaktır. Araştırma kapsamında Tokat merkez ilçeye bağlı köylerde birleştirilmiş sınıf uygulaması yapılan 20 ilköğretim okulunda bu sinıflarda görev alan 33 öğretmene ve bu okullara Gaziosmanpaşa Üniversitesi Eğitim Fakültesi İlköğretim Bölümü Sınıf Öğretmenliği Anabilim Dalı 4. sınıf "birleştirilmiş sınıflarda öğretim "dersi kapsamında uygulamaya giden 60 öğrencinin yaptıkları gözlem ve uygulama sonucuna göre anket yoluyla görüşleri alınarak öğretmenlerin görüşleriyle karşılaştırılarak değerlendirilmeye çalışılmıştır. Araştırmada frekans (f) ve yüzde (\%) değerleri kullanılmıştır. Bu çalışmada niteliksel olarak anketin açı uçlu sorularına verilen cevaplardaki ifadelerin orijinal olanları örnek ifadeler şeklinde verilmiştir.
\end{abstract}

Anahtar Sözcükler: Birleştirilmiş sınıflar, eğitim sorunları ve çözüm önerileri

\section{Abstract}

The purpose of the present study was to identify the problems encountered in elementary multi-age classrooms in Turkey. The views of teachers who are working in multi-age classrooms and teachers-in-training who will probably start working in such classrooms after graduation were obtained and contrasted. The sample of the study consisted of 33 elementary school teachers who were working in 20 different schools around suburban Tokat and 60 teachers-in-training who were doing their teaching practicum as a part of the degree requirement in the course of "teaching in multi-age classrooms." The views of the teachers were collected through a questionnaire. Teachers-in-training made observations in multi-age classrooms within their practicum. Frequency analyses and percentages were computed to analyze the data. In addition, qualitative results were presented based on the responses given to open-ended questions in the questionnaire. Discussion is based on the results obtained and suggestions are given.

Keyword: Multi-age classrooms; Educational problems; Suggested-solutions

${ }^{a}$ Öğr. Gör. Gaziosmanpaşa Üniversitesi, Eğitim Fakültesi, Tokat, fevzid@gop.edu.tr 


\section{Giriş}

Ülkemizde geçmişte öğretmen ve derslik sayısının yetersizliği, günümüzde ise öğrenci azlığı gibi nedenlerle özellikle köy ilköğretim okullarında birleştirilmiş sınıflı öğretim uygulaması yapılmaktadır.

Birleştirilmiş sınıflar uygulaması ilköğretimde birden fazla sınıfın birleştirilerek aynı sınıfta bir öğretmen tarafından ders yapılmasıdır, bu uygulama yalnızca ülkemize özgü değil dünyanın birçok ülkesinde başvurulan bir öğretim şeklidir (Fidan ve Baykul, 1993: 2).

Birleştirilmiş sınıf uygulaması köye yönelik bir öğretim uygulaması olmasının yanında, ülkemiz eğitim sistemi içinde yer alan sekiz yıllık ilköğretim uygulamasının birinci kademesine(1.2.3.4.5. sınıflara) yönelik bir uygulamadır (Erdem, 2004: 10).

Türkiye'de (MEB, 2005) 2004-2005 eğitim-öğretim yılı verilerine göre; 16.379 ilköğretim okulunda 587.379 öğrenci birleştirilmiş sınıflı okullarda eğitim görmektedir. Türkiye deki tüm ilköğretim okullarının (35.580) yaklaşık olarak \% 40.03'ü birleştirilmiş sınıfı bulunan ilköğretim okullarından oluşmaktadır.

Birleştirilmiş sınıf uygulaması Türkiye'nin bütün illerinde uygulanıyor. Birleştirilmiş sınıf uygulaması kapsamındaki öğrencilerden 238 bin 343'ü iki, 178 bin 6'sı üç, 18 bin 194'ü de dört sınıf bir arada öğrenim görüyor. Beş sınıf bir arada öğrenim gören öğrenci sayısı ise 152 bin 836'ya ulaşıyor. Birleştirilmiş sınıflarda eğitim veren öğretmen sayısı 27 bin 685'dir (Radikal Gazetesi, 2005). İstatistiklere göre mevcut ilköğretim okullarının yarısına yakını birleştirilmiş sınıflı okullardır. Bu okullarda görev yapan öğretmen ve öğrenim gören öğrenci sayısı bağımsız sınıflardakilerin yaklaşık (\% 10)'u kadardır.

Birleştirilmiş sınıflarda öğretim, ülkemiz milli eğitiminde çok eskiden beri uygulanmaktadır. Türkiye'de bu uygulamayı zorunlu kılan üç temel neden vardır. Bunlar; öğrenci sayısının azlığı, öğretmen sayısının azlığı ve derslik 
sayısının yetersizliğidir. 16 bin 379 birleştirilmiş sınıflı okulun, 7 500'ünün tek öğretmenli olması, öğrenci sayısının azlığının en önemli neden olduğunu göstermektedir.

Köksal(2005: 8)'a göre Türkiye'de birleştirilmiş sınıflarda öğretim uygulanmasını zorunlu kılan nedenler öğretmen, öğrenci ve derslik sayısının yetersizliğidir, ancak son yıllarda daha çok köyden kente göç vb nedenlerle köydeki öğrenci sayısının azalması asıl nedendir.

Birleştirilmiş sınıflarda öğretim yapılmasını zorunlu kılan sosyal ve ekonomik nedenler; öğretmen sayısının yetersiz olması, köyden kente göçle köydeki okullardaki öğrenci sayısının azalması ve müstakil sınıf açmanın ekonomik olmaması yüzünden birleştirilmiş sınıf uygulamasına başvurulması, bunun yanında taşımalı öğretim yapan köy okullarının yeniden açılması gibi sebeplerle bu uygulamaya başvurulmaktadır (Erdem, 2004: 11).

Şahin (2003) tarafından yapılan araştırmada birleştirilmiş sınıf uygulamasının öğretmenlerin mesleki heyecan ve motivasyonları üzerinde olumsuz etkileri olduğu ve birleştirilmiş sınıflarda görev almak istemedikleri ortaya çıkmıştır. Ayrıca öğretmenler uygulama süreci ve sonuçlanı dışında ulaşım, barınma, sosyal yaşam, temel gereksinimlerin karşılanmasında yaşanan güçlükler gibi gerekçeler nedeniyle birleştirilmiş sınıf uygulamasına son verilmesi gerektiğini belirtmişlerdir.

Çınar'ın (2004) Malatya da 240 öğretmen üzerinde yaptığı araştırmada; birleştirilmiş sınıflı okullarda öğretmenler her sınıf için gerektiği kadar zaman ayıramadığı, okullarda araç gereç eksikliği bulunduğu, velilerin eğitime beklenen katkı ve desteği sağlamadıkları, öğretmenler mesleki gerileme içine girdiklerini de ifade etmişlerdir.

Erdem, Kamacı ve Aydemir (2005) Denizlide 62 birleştirilmiş sınıf okutan öğretmenlerle yaptı̆̆ 1 araştırmada; öğretmenlerin \% 93 düzeyinde "kısmen" sorun yaşadıklarını ve bu sorunların cinsiyete, öğrenci sayısına, mezun olunan okula, göreve, mesleki kıdeme, birlikte görev yapılan öğretmen sayısına, okutulan birleştirilmiş sınıf grubuna, birleştirilmiş sınıfı okuttuğu yıla, ikametgâha göre farklılık gösterdiği belirtilmiştir.

Gültekin (2005) çalışmasında ilköğretimde yaygın olarak uygulanan birleştirilmiş sınıflarda öğretime ilişkin araştırma sonuçları dikkate alındığında, 
normal ilköğretim okullarında öğrenim görme olanağı olmayan öğrencilerin öncelikle taşımalı eğitimle öğrenim görmesi, değilse YİBO ya da PİO'lara alınması ve birleştirilmiş sınıflarda öğretim uygulamasına zamanla son verilmesi gerektiği ortaya konulmuştur.

Kılınç (2005) tarafından yapılan; Birleştirilmiş ve Normal Sınıflarda Okuyan 4. ve 5. Sınıf Öğrencilerinin Türkçe ve Matematik Derslerindeki Başarılarının Karşılaştırılması adlı çalışmada 2003-2004 öğretim yılında Gaziantep ili merkez ilçelerinde yer alan birleştirilmiş ve normal sınıflarda okuyan 4. ve 5. sınıf öğrencilerinin, Türkçe ve matematik derslerindeki başarıları arasındaki fark belirlenmeye çalışılmıştır. Araştırma sonucunda normal öğretim yapan okullardaki 4. ve 5. sınıf öğrencilerinin birleştirilmiş sınıf öğrencilerine göre Türkçe ve matematik dersinde daha başarılı oldukları ortaya çıkmıştır.

Akpınar, Turan \& Gözler (2006) yaptığı çalışmada birleştirilmiş sınıflarda görev yapan öğretmenlerinin zaman yetersizliği, birleştirilmiş sınıflarda eğitimöğretim ve öğretmenli-ödevli ders işleme konularında en çok matematik dersinde ve ayrıca yine Türkçe dersinde zorlandıklarını, yine öğretmenler araçgereç temin etme konusunda en çok fen bilgisi dersinde ve matematik de zorlandıklarını, fen bilgisi, Türkçe, matematik, başta olmak üzere ilköğretim programının birleştirilmiş sınıflar göz önüne alınarak düzenlenmesi gerektiğini ifade etmişlerdir.

Dalka, S. (2006) birleştirilmiş sınıflarda görev yapan 95 adet öğretmenle yaptığı çalışmada yeni programın birleştirilmiş sınıflı okullarda uygulanması ve başarı elde edilmesi, bu okulların bugünkü halleriyle imkânsız olduğunu, yapılandırmacı yaklaşım için okullarda olması gereken asgari fiziki imkânların okullarda bulundurulması gerektiği ifade edilmiştir.

Birleştirilmiş sınıflarda görev yapan öğretmenler, genellikle meslekî yaşamlarının ilk yıllarını çalışmaktadırlar. İlk yıllarda, ne kadar nitelikli hizmet öncesi eğitim alınmış olunursa olunsun, öğretmenler birçok zorluğu bir arada yaşarlar. Öğretmenlerin öğrenmiş olduklarını bilgilerin yetersizliği, yaşadıkları tecrübelerin azlığı birleştirilmiş sınıf öğretimindeki sorunları daha da artırmaktadır. 
Birleştirilmiş sınıflarda öğretimin sakıncalı yanlarını Köksal (2005: 12) şöyle sıralamaktadır; öğretmenin görev, yetki ve sorumluluklarının boyutunun artması, öğretmenin derse hazırlık için harcadığı zaman ve enerjinin artması, ilköğretim programındaki hedeflerin tümüne ulaşmanın güçleşmesi, sınıf öğretmenliği yapanların tümünün, birleştirilmiş sınıf uygulaması konusunda yeterli bilgi ve birikime sahip olmaması ve öğretmenlerin gerektiği kadar rehberlik hizmeti alamamasıdır. Birleştirilmiş sınıflarda öğretimin sakıncalı yanları sadece yukarıdaki konular olmayıp bunlar artırılabilir.

Eğitim sen (2005) Yeni İlköğretim Müfredatının Değerlendirilmesi adlı açıklamasında: birleştirilmiş sınıflarda ilk okuma yazma öğretiminin (Birinci sınıf ayrı, iki-üç ve dört-beş birleştirilmiş veya bütün sınıflar birleştirilmiş ya da bir, iki ve üçüncü sınıf ile dört ve beşinci sınıf birleştirilmiş) ve Türkçe dersinin işlenmesinin nasıl olacağı programda açıklanmamış ve gerekli düzenlemeler yapılmamış ve yeni ilköğretim müfredatının birleştirilmiş sınıflarda nasıl uygulanacağının belirsizliği ve aynı salonda beş ayrı sınıf okutan öğretmenin, bu müfredatı nasıl uygulayacağına yönelik yeni ilköğretim müfredatında bir yol ya da çözüm belirtilmediği ifade edilmiştir.

Ülkemizde ilköğretim okullarının 1. kademesinde uygulanmak zorunda kalınan birleştirilmiş sınıflarda öğretim uygulaması çeşitli sorunlar yaşanmaya devam edilmekte olup uygulanmaya başlanan yeni programla ve yeni yetişen öğretmenlere ve yeni teknolojilere rağmen bu sorunlar ortadan kalkmamıştır. Devam eden bu sorunlar nelerdir ve nasıl çözülebilir; bir anlamda bunu ortaya koymak araştırmanın problemidir.

\subsection{Amaç}

$\mathrm{Bu}$ araştırmanın amacı; ilköğretim okullarında uygulanan birleştirilmiş sınıflarda öğretim uygulamasının sorunlarını belirleyerek öğretmen ve öğretmen adaylarının konuya ilişkin çözüm önerilerini belirlemektir. Öğretmen adayı olarak lisans eğitimlerinin son aşamasında olan sınıf öğretmeni adaylarının sınıf öğretmeni olarak ilk atamaları büyük olasılıkla birleştirilmiş sınıflı bir okula olması yüksek olduğundan bunların görev yapmadan bu uygulama hakkında görüşlerini almak ve bu görüssleri öğretmenlerin görüşleri ile karşıtlaştırılmasının gerekli olduğu düşünülmüştür. 
Öğretmenlerin bu süreçte karşılaştıkları sorunlarını ve bu sorunların çözümü için çözüm önerilerini belirlemek ve öğretmen, öğretmen adaylarının görüşlerini karşılaştırmak amacıyla aşağıdaki sorulara yanıt aranmıştır.

\subsubsection{Alt Amaçlar}

a) Öğretmene göre yeni program (yapılandırmacılık) konusundaki gelişmeler birleştirilmiş sınıflardaki öğretimi nasıl etkilemiştir.

b) Birleştirilmiş sınıflarda öğretim yapan öğretmenlere göre;

- Öğretmenin öğretim sürecinde kullandığı yöntem ve teknikler, kullandığı kaynak, araç-gereç teknolojiler nelerdir?

- Birleştirilmiş sınıflarda öğretimin sorunları nelerdir?

- Birleştirilmiş sınıflardaki öğretimin faydaları nelerdir?

- Birleştirilmiş sınıflardaki öğretimin Sakıncaları nelerdir?

- Öğretmenin birleştirilmiş sınıflarda daha iyi eğitim ve öğretim yapabilmesi için; neler yapılmalıdır, sorunların çözümü için önerileri nelerdir?

c) birleştirilmiş sınıflarda uygulama yapan öğretmen adaylarına göre;

- Öğretmenin öğretim sürecinde kullandığg yöntem ve teknikler, kullandığı kaynak, araç-gereç teknolojiler nelerdir?

- Birleştirilmiş sınıflarda öğretimin sorunları nelerdir?

- Birleştirilmiş sınıflardaki öğretimin faydaları nelerdir?

- Birleştirilmiş sınıflardaki öğretimin Sakıncaları nelerdir?

- Öğretmenin birleştirilmiş sınıflarda daha iyi eğitim ve öğretim yapabilmesi için; neler yapılmalıdır, sorunların çözümü için önerileri nelerdir?

d) birleştirilmiş sınıflarda öğretim yapan öğretmen ile yine bu sınıflarda uygulama yapan öğrencilerin görüşleri arsındaki farlılıklar ve bezerlikler nelerdir.

\section{2- Yöntem}

$\mathrm{Bu}$ araştırmada birleştirilmiş sınıf öğretimi yapılan okullarda görev yapan öğretmenlerin görüşlerine ve sınıf öğretmenliği anabilim dalı dördüncü sınıf birleştirilmiş sınıflarda öğretim dersi kapsamında uygulamaya giden öğretmen adaylarının görüşlerine göre betimsel tarama yönteminden yararlanarak ortaya konmaya çalışılmıştır. 


\subsection{Evren ve Örneklem}

Araştırmanın evreni Tokat ilidir. Bu evrenden uygulama için öğrencilerin kolay ulaşım sağlayabileceği düşünülerek seçilen, Merkez ilçeden 20 okul öğretmen adaylarının ulaşım kolaylığı vs mecburiyeti yüzünden örnekleme alınmıştır. Toplam 33 öğretmen ve 6o öğretmen adayına anket uygulanmış ve veriler yorumlanmıştır.

\subsection{Verilerin Toplanması}

Örneklemde yer alan birleştirilmiş sınıflı okullarda öğretmenlerden ve 2005-2006 öğretim yılı bahar yarıyılındaki sınıf öğretmenliği anabilim dalı dördüncü sınıf "birleştirilmiş sınıflarda öğretim" dersi kapsamında uygulamaya giden öğretmen adaylarından araştırma için geliştirilen anket yoluyla toplanmıştır.

Anket iki bölümden oluşmuştur. Birinci bölümde öğretmenlerin kişisel özellikleri, ikinci bölüm ise birleştirilmiş sınıf uygulamasına ilişkin bilgileri içermektedir. Öğretmen adaylarına anketin sadece ikinci kısmı uygulanmıştır.

Anketi 2006 yılı Mayıs ayında Tokat ili merkez ilçede birleştirilmiş sınıflarda öğretmenlik yapan 33 öğretmene görüşme yoluyla cevaplandırmaları sağlanmış ve aynı anket Tokat ili merkez ilçede 20 okula "birleştirilmiş sınıflarda öğretim” dersi kapsamında gerekli izinler alınarak iki hafta uygulamaya giden 60 öğretmen adayına gözlemleri sonucunda doldurmaları sağlanarak görüşleri alınmıştır.

\subsection{Verilerin İşlenmesi ve Çözümlenmesi}

Öğretmen ve öğretmen adaylarının ankete verdiği cevaplar alınarak bir araya getirilip gruplandırılarak çözümlemeleri yapılmıştır. Elde edilen bulgular alan yazına dayalı olarak yorumlanmıştır.

Elde edilen veriler frekans (f) ve yüzde (\%) olarak ifade edilmiş, açık uçlu sorulara verilen cevaplar, öğretmenlerin ve öğretmen adaylarının en çok ifade ettikleri, genel olarak birleştikleri ifadeler aynen orijinal ifade örnekleri olarak araştırmaya nitel bir boyut kattığı için verilmiştir.

\section{Bulgular}

\section{1. Öğretmenlerin kişisel Özellikler}

$\mathrm{Bu}$ bölümde birleştirilmiş sınıflarda görev yapan öğretmenlerin kişisel özellikleri; cinsiyet, yaş, mezuniyet, kıdem, kaç yıldır birleştirilmiş sınıf 
okutuyor, öğretmenlerin birleştirilmiş sınıflarda öğretim konusundaki eğitimleri ne durumda, bu eğitimi alma biçimleri nasıldır? Sorularına verilen cevaplar frekans(f) ve yüzde( \%) olarak verilmiş ve öğretmenlerin genel olarak birleştikleri ifadeler orijinal ifade örnekleri olarak aynen verilmiş ve yorumlanmaya çalışılmıştır.

Öğretmenlerin kişisel bilgileriyle ilgili veriler incelendiğinde; cinsiyet: bayanlar f:11, \%33.34, erkekler f:22, \% 66.66, yaş: 25-40 yaş arası f:25, $\% 75.75$ ve 41 ve üstü f:8, \% 24.25, mezuniyet: sınıf öğretmenliğinden mezun olanlar f:17, \% 51.51, diğer bölümlerden mezun olanlar f:16, \%48.49, kıdem: 1-5 y1l f:4, \% 12.12, 6-10 yıl f:20, \% 60.60, 11-15 yıl f:4, \% 12.12, 16-20 y1l f: 1, \% 3.04, 21 yıl ve üzeri f:4, \% 12.12' kaç yıldır B.S.Ö. öğretmenisiniz: 1-5 yıl f:14, \% 42.43, 6-10 y1l f:15, \% 45.45, 11 yll ve üzeri f:5, \% 12.12'dir.

Birleştirilmiş sinfflarda öğretim konusundaki eğitimleri: eğitim almayanlar f:16, \% 48.49, eğitim alanlar f:17, \% 51.51, eğitim alanların aldıkları eğitimin türü: yüksek öğrenimim sırasında f:12,\% 70.59, hizmet içi eğitim kursunda f:4, \% 23.52, stajyerlik döneminde f:1, \% 3.03.

$\mathrm{Bu}$ verilerden anladığımıza göre erkek öğretmenlerin çoğunlukta olduğunu, grubun çoğunluğunun 25-40 yaş arasında (\%75.75) yoğunlaştı̆̆ını, grubun yarıya yakınının (\%48.49) sınıf öğretmenliği dışında bir alandan mezun olduklarını, bu alan dışındaki mezun olunan (fakülte/ bölüm/ anabilim dalı) branşlar; (16 kişi) ziraat fakültesi bahçe bitkiler, tarla bitkileri, fen edebiyat fakültesi biyoloji, fizik, kimya, tarih, sosyoloji, almanca, Dil Tarih Coğrafya Fakültesi Hindoloji, İktisadi Ve İdari Bilimler Fakültesi maliye, Siyasal Bilgiler Fakültesi kamu yönetimi, Beden Eğitimi Ve Spor Yüksek Okulu beden eğitimi öğretmenliği, açık öğretim fakültesi önlisans tamamlama gibi farklı programların olduğu görülmektedir. Eğer bu kadar küçük bir grupta 33 kişiden branş dışından gelen sınıf öğretmenleri olduğuna göre sınıf öğretmenliği branşı dışından mezun olanların azımsanamayacak kadar büyük bir oranı kapsadığı söylenebilir, kıdem açısından merkeze yakın köy olduğu için ve branşında sınıf öğretmenliği olmasından ötürü 5-10 yıl kıdeme sahip olanların ağırlıkta olduğu, B.S.Ö. öğretmenlik yapma açısından baktığımızda ise 6-10 yıl arasında görev yapanların çoğunlukta olduğu görülüyor.

\section{2. Öğretmenlerin yeni programa ilişkin görüşleri}


- Bireysel farklılıklar birleştirilmiş sınıflarda fazla olduğu için bazı etkinlikler öğrencilere ağır geliyor,

- Birleştirilmiş sınıflarda bu programı ve programdaki etkinlikleri uygulamak zor,

- Öğretmenlere yeterli kurs ve seminerler verilmedi,

- Yeni program birleştirilmiş sınıf uygulamasını dikkate almamıştır,

- Yeni programdaki ayrıntıları köyde uygulamak mümkün görünmüyor

- Öğrenciler kendi eserleri olan ürün dosyalarını etrafındakilere gösterme hazzını yaşadılar,

- Öğretmen plana harcayacağı zamanı hazırlanmaya harcayabilir,

Yukarıdaki ifadelere bakıldığında birleştirilmiş sınıflarda öğretim yapan öğretmenlerin yeni programı ilişkin olumlu ve olumsuz görüşleri bulunmaktadır. Programı birleştirilmiş sınıf uygulamasına nasıl yansıtacaklarını anlamadıklarını görüyoruz.

\subsection{Birleştirilmiş sınıflarda öğretim yapan öğretmenlerin görüşleri}

$\mathrm{Bu}$ bölümde; birleştirilmiş sınıflarda öğretim yapan öğretmenlerin öğretim sürecinde kullandığı yöntem ve teknikler, kullandığı kaynak, araç-gereç teknolojiler, öğretmene göre birleştirilmiş sinıflarda öğretimin sorunlar, birleştirilmiş sınıflardaki öğretimin faydaları, birleştirilmiş sınıflardaki öğretimin sakıncaları, öğretmenin birleştirilmiş sınıflarda sorunların çözümü için önerileri toplanmış. Elde edilen veriler frekans(f) ve yüzde( \%) olarak verilmiş ve öğretmenlerin genel olarak birleştikleri ifadeler orijinal ifade örnekleri olarak aynen verilmiş ve yorumlanmaya çalışılmıştır.

3.3.1. Öğretmenlerin öğretim sürecinde kullandığı yöntem ve teknikler Öğretmenlerin kullandığı yöntemlere baktığımızda; anlatım f:26, \% 35.19, soru cevap f:26, \% 35,1, uygulama f:12, \% 16,2, gezi-gözlem f:10, \% 13,5, drama f:7, \% 9.45, tartışma f:7, \% 9.45, gösterip yaptırma f:7, \% 9.45, problem çözme f:5, \% 6.75, grup çalışması f:5, \% 6.75, beyin firtınası f:4, \% 5,4, rol yapma f:4, \% 5,4, araştırma-inceleme f:4, \% 5,4, deney f:2, \% 2,7, eğitsel oyunlar f:2, \% 2,7, okuma f:2, \% 2,7, küme çalışması f:2, \% 2,7, proje çalışması f:2, \% 2,7, büyüklerin rehberliği f:2, \% 2,7, grup etkinlikleri(kavram haritası vb.)f:2, \% 2,7, gösteri f:1, \% 1.35, seviye grupları f:1, \% 1.35, kubaş1k 
öğrenme yöntemi f:1, \% 1.35 ve bireysel çalışma yöntemi f:1, \% 1.35, olmak üzere toplam 33kişi tarafından değişik yöntemler (n) 135 defa ifade edilmiş.

$\mathrm{Bu}$ verilerden anladığımıza göre anlatım, soru cevap ve uygulama en çok kullanılan; araştırma-inceleme, deney, eğitsel oyunlar, proje çalışması, büyüklerin rehberliği, gösteri, seviye grupları ve bireysel çalışma yöntemi gibi yöntemlerin en az kullanılan yöntemler arasında olduğu görülmektedir. Buradan birleştirilmiş sınıf öğretimi yapan öğretmenlerin ağırlıklı olarak geleneksel öğretim yöntemlerini kullanmaya devam ettiğini, ayrıca birleştirilmiş sınıflarda öğretim alanının kendi özelliğinden dolayı bu alanda kullanılan; küme çalışması, büyüklerin rehberliği, seviye grupları ve bireysel çalışma yöntemi gibi yöntemlerinde en az kullanılan yöntemler arasında olduğu söylenebilir.

3.3.2. Öğretmenlerin öğretim sürecinde kullandığı kaynak, araçgereç ve teknolojiler

Öğretmenlerin kullandığı araç-gereçlere baktığımızda; ders kitabı ve diğer kitaplar f:24, \% 21,05, tepegöz f:12, \% 10,53, bilgisayar f:10, \% 8,77, mikroskop f:9 \% 7,89, TV f:6, \% 5,26, çizgi film CD’si f:6, \% 5,26, haritalevha f:5, \% 4,38, resimler-tablolar f:5, \% 4,38, ansiklopedi f:4, \% 3,50, matematik seti f:4, \% 3,50, mevsim şeridi f:4, \% 3,50, DVD f:3, \% 2,63, internet f:3, \% 2,63, küre f:3, \% 2,63, tarih şeridi f:3, \% 2,63, bilgisayar çıktıları $\mathrm{f}: 2, \%$ 1,75, ögretmen kılavuzu f:2, \% 1,75, fen dolabı f:1, \% 0,88, test kitapları $\mathrm{f}: 1, \%$ 0,88, bilgisayar-CD f: $1, \% 0,88$, çevremiz ve ailemizi f: $1, \% 0,88$, pergeliletki-gönye f: $1, \%$ 0,88, çizgi film CD'si f:1, \% 0,88, cetvel f:1, \% 0,88, fotokopi f:1, \% 0,88, atlas f:1, \% 0,88 olarak toplam 33 kişi tarafından 27 değişik araç (n) $127 \mathrm{kez}$ ifade edilmiş.

$\mathrm{Bu}$ verilerden öğretmenlerin kullandığı araç-gereçler içersinde en çok ders kitabı, tepegöz, bilgisayar, mikroskop, TV, çizgi film CD'si gibi araçlar olduğu; bunun yanında bilgisayar çıktıları, öğretmen kılavuzu, fen dolabı, test kitapları, bilgisayar-CD, fotokopi, atlas gibi araçlar ise en az kullanılan araçlar arasında olduğu söyleyebiliriz.

3.3.3. Öğretmenlere göre birleştirilmiş sınıflarda öğretimin sorunları

- Aynı ders saatinin birden fazla sinıfa ayrılması,

- Birleştirilmiş sınıf uygulaması olan yerler genelde araç gereçten (TV, fotokopi vb.) yoksun olmasi, 
- Ders saatlerinin yeterli olmaması, konuların eksik kalması,

- Farklı sınıf seviyelerinin bir arada olması,

- Müstakil sınıfla birleştirilmiş sınıflarda öğretim sınıfında aynı zaman süresinde aynı programın uygulanması hedeflere ulaşmayı engelliyor,

- Öğrencilere bireysel olarak yeterli miktarda vakit ayrılamıyor,

- Öğretmenli grupla ders işlerken diğer ödevli gruptaki öğrenciler tarafından dersin bölünmesi,

- Rehberlik ve sosyal etkinliklere yeterli zamanın olmaması,

- Sinıfta hâkimiyet kuramama, sınıfta kargaşanın olması,

- Sosyal ve kültürel yönleri farklı ve zayıf olan ailelerinin çocuklarına programın kazanımlarını sağlamak zordur,

İfadelerden de anlaşıllyor ki öğretmenlere göre; öğrencilere bireysel ilgi verilemiyor, veliler ilgisiz, zaman yetmiyor, hedeflere tam ulaşılamıyor.

3.3.4.Öğretmenlere göre birleștirilmiş sınıflardaki öğretimin faydaları

- Bazı öğrencilerin diğer sınıfı dinlerken bir ileriki seviyedeki konuyu öğrenmesi,

- Bilenlerin bilmeyenlere öğretmesi,

- Bireysel çalışma yöntemi ile öğrenci kendi kendine çalışmayı kavrıyor ve kendine göre yöntem belirleyebiliyor,

- Bu tür sınıflarda konular fazla tekrar edildiği için pekiştirici olmaktadır,

- Büyük ve küçük öğrenciler arasında yardımlaşma ve paylaşmayı sağlaması,

- Büyüklerin küçük öğrencilere örnek olması öğretmenin eğitsel olarak yükünü hafifletiyor,

- Öğrenciler yardımlaşma ile birbirlerinden öğrenebiliyorlar,

- Öğrencilerin grupla çalışması ve bağımsız çalışması, paylaşım gibi duygularının gelişmesi,

Genel olarak öğretmenlere göre; bu uygulama biçiminin daha çok yardımlaşma paylaşma ve öğrencilerin sosyalleşmesini artırdığını söyleyebiliriz.

3.3.5. Öğretmenlere göre birleştirilmiş sınıflardaki öğretimin sakıncaları 
- Birden fazla sınıf bir arada öğretim gördüğü için zaman yetersiz kalmaktadır,

- Büyükler küçükler üzerinde hâkimiyet kuruyor,

- Dikkat çekme, güdülenme tekrar, pekiştirme yeterince yapılamıyor,

- Ortak derslerde ödevli grup da sıkılan öğrenciler sorun çıkarıyor,

- Ödevli grubun dikkat eksikliğinden gerekli verimin alınamaması,

- Ödevli gruptaki öğrenci kendini ödevli olduğu konuya vermezse öbür grubun konusuyla kendi konusunu karıştırıyor,

- Öğrenciler arasındaki yaş farkları kaynaşmalarını geciktirir,

- Öğretmenli ders işlerken ödevli diğer grup tarafından bölünmesi

- Yeterli uygulama ve tekrar için zamanın yetmemesi,

İfade edilenlerden öğretmenlerin; bu uygulamada zamanın yetersiz kalması, büyüklerin küçükler üzerinde hâkimiyet kurması, tekrar ve pekiştirmenin yapılamaması, ödevli grubun dikkat eksikliğinden gerekli verimin alınamaması gibi değişik sakıncaları olduğunu vurgulamışlardır.

\subsection{6. Öğretmenlerin birleştirilmiş sınfflardaki sorunlara çözüm önerileri}

- Birleştirilmiş sınıf okutacak öğretmenler bu sınıflarda özel olarak adaylık eğitimi almalıdır,

- Derslerdeki etkinlikler birleştirilmiş sınıflara göre hazırlanabilir,

- Norm kadrolara artırılarak mümkün olduğunca az birleştirilmiş sınıf uygulaması yapilmalı,

- Öğrencilerin ailelerle iyi iletişim kurarak, işbirliği yapılmalı,

- Sene başından itibaren gözlemleyerek seviye grupları oluşturulmalı,

- Üst sinıflardan veya konuyu iyi öğrenenlerden yardım alabiliriz,

- Yakın köylerdeki öğrenciler uygun bir yerde toplanarak öğretmen ve diğer imkânlar daha verimli kullanılabilir,

Belirtilen ifadelerden öğretmenlere göre çözümün; bu uygulamanın mümkün olduğunca kaldırılmasıyla, programın ve etkinliklerin bu uygulamaya göre düzenlenmesiyle olabileceğini belirtmişlerdir.

3.4. Birleştirilmiş sınıflarda uygulama yapan öğretmen adaylarının görüşleri 
Bu bölümde uygulama yapan öğretmen adayı öğrencilerin; köyün genel durumu, okulun sınıfın durumu hakkında izlenimleri, öğretmenlerin öğretim sürecinde kullandığı yöntem ve teknikler, kullandığı kaynak, araç-gereç teknolojiler, öğretmene göre birleştirilmiş sinıflarda öğretimin sorunlar, birleştirilmiş sınıflardaki öğretimin faydaları, birleştirilmiş sınıflardaki öğretimin sakıncaları, birleştirilmiş sınıflarda sorunların çözümü için önerileri kendi ifadeleri ile verilmeye çalışılmıştır.

\subsection{1. Öğretmen adaylarına göre genel durum}

Toplam 20 birleştirilmiş sınıf uygulaması olan ilköğretim okulunda uygulamaya giden 60 öğretmen adayı öğrencinin gözlem ve görüşleri değerlendirildiğinde; 20 okulda; a) 1-23-45 olarak bir müstakil iki birleştirilmiş, b) 123-45 olarak iki birleştirilmiş sınıf, c) 12345 beşi bir arada olarak tek birleştirilmiş sınıf, d) 123-45 olarak iki birleştirilmiş sınıf, e) 1-2-345 olarak üç müstakil bir birleştirilmiş sınıf ve f) 12-345 olarak iki birleştirilmiş sınıf şeklinde altı farklı uygulama biçiminin uygulandığı görülmektedir. Öğrenci sayısı 9 ile 72 kişilik okullar olarak aşırı bir değişiklik göstermekte olup, bu yirmi okulda birleştirilmiş sınıf okutan öğretmen bir veya iki kişidir.

Uygulamaya giden 60 öğretmen adayının köylerin, okulluların ve sınıfların genel durumu hakkındaki olumlu izlenimleri şöyledir;

- Ailelerden bazıları öğrencilerin eğitimiyle birebir ilgileniyor,

- Bahçe alanı çok güzel, bahçe çok büyük,

- Köy halkının eğitime bakış açısı olumluydu

- Okul binası fiziksel olarak bakımlı ve temiz,

- Okulun bahçesi öğrencilerin koşup oynamalarına elverişliydi,

- Sıraların üzerine minderler yerleştirilmiş ve masalar alttan lastikli örtülerle kaplanmış

\section{Olumsuz izlenimleri ise;}

- Aileler çocuklarını okula gönderiyor fakat oldukça ilgisizler,

- Bahçesi büyük ama çok bakımsız,

- Çocuklar okuma- yazma öğrensinler yeter diye düşünülüyor,

- Genelde her köyde bir lojman var ama oturan yok,

- Kitaplık odası sanki hiç kullanılmıyormuş gibi bir köşeye atılmışı, 
- Köy halkı çocukların eğitimiyle yakından ilgilenmediği için çocukların okul ihtiyaçları öğretmenler tarafından şehirden karşılanıyor,

- Kullanılmak amaciyla herhangi bir teknolojik (TV, VCD, projeksiyon makineleri vs.) araç bulunmamaktadır,

- Okuldaki en büyük sorun 1sınma ve teknolojik eksiklikler,

- Öğrencilerinde eğitime pek de hevesle baktığını gözlemleyemedim,

- Sınıf görünümü öğrencilerin ilgilerini çekecek nitelikte değil,

- Sinıflar yeterince hava ve güneş ışığı alamıyor,

- Sobaları çocuklar yaktığından sınıf ya çok sıcak ya çok soğuk oluyor,

- Tuvalet olmaması ve okulun sularının akmamasıydı,

Daha çok olumsuz ifadelerden anlayacağımız gibi genel olarak velilerin ilgisizliği, ısınma ulaşım temizlik vs alanlarda hala sorunlar yaşanmaya devam ettiğini söyleyebiliriz.

\subsection{2. Öğretmen adayına göre öğretmenlerin öğretim sürecinde kullandığı yöntem ve teknikler}

Öğretmen adaylarına göre öğretmenlerin kullandığı yöntem ve tekniklere baktığımızda; anlatım f:50, \% 28.57, soru cevap f:50, \% 28.57, tartışma f:13, \% 7.43, beyin firtınası f:9, \% 5.14, drama f:6, \% 3.43, gözlem f:5, \% 2.86, gösterip yaptırma f:4, \% 2.29, problem çözme f:4, \% 2.29, araştırma-inceleme f:3, \% 1.71, gösteri f:5, \% 2.85, proje çalışması f:3, \% 1.719, uygulama f:2, \% 1.14, gezi-gözlem f:2, \% 1.14, bilgisayar destekli öğretim f:2, \% 1.14, okuma f:2, \% 1.14, grup çalışması $\mathrm{f}: 2, \% 1.14$, portfolyo( ürün dosyası) $\mathrm{f}: 2, \% 1.14$, rol yapma f: $1, \% 0.57$, deney f: $1, \% 0.57$, siz olsaydınız ne yapardınız etkinliği f: $1, \% 0.57$, eğitsel oyunlar f:1, \% 0.57, küme çalışması f: $1, \% 0.57$ büyüklerin rehberliği $\mathrm{f}: 1, \%$ 0.57, dinleme f:1, \% 0.57, grup etkinlikleri (kavram haritası vb.) f:1, \% 0.57 , seviye grupları f: $1, \% 0.57$, tahmin etme- menekşe-papatya etkinliği f: $1, \%$ 0.57 , örnek olay f: $1, \% 0.57$ olmak üzere 60 öğretmen adayı tarafından 29 farklı yöntem toplam (n) 175 defa ifade edilmiş.

Öğretmen adaylarının verdikleri bu bilgiler göre öğretmenlerin en çok kullandığı yöntem ve teknik olarak; anlatım, soru cevap, tartışma, beyin fırtınası gibileri yer almaktadır. En az ise gözlem, gösterip yaptırma, araştırma-inceleme, uygulama, gezi-gözlem, bilgisayar destekli öğretim, rol yapma, deney, eğitsel 
oyunlar, küme çalışması, büyüklerin rehberliği, seviye grupları ve örnek olay gibi yöntemleri görünmektedir. Öğretmen adayları da birleştirilmiş sınıf öğretimi yapan öğretmenlerin genel olarak geleneksel öğretim yöntemlerini kullanmaya devam ettiği ayrıca birleştirilmiş sınıflarda öğretim alanının kendi özelliğinden dolayı bu alanda kullanılan; küme çalışması, büyüklerin rehberliği, seviye grupları gibi yöntemler en az kullanılan yöntemler arasında olduğu söylenebilir.

Öğretmen adaylarının uygulandığını gördükleri örnek bir kaç etkinliklerin (fasulyenin uzamasıyla ilgili gözlem sonuçlarına dayanan bir grafik oluşturulmuş, aile soy ağacı oluşturma, bir haftalık hava durumunun gözlenmesi ve tablo haline getirilmesi) eskiden beri kullanılanlar olduğu, yeni programla ortaya konulan etkinliklerle ilgisinin olmadığını, bununda öğretmenlerin yeni program hakkındaki eğitimlerinin yetersizliğini gösteren bir ipucu olduğunu belirtebiliriz.

3.4.3. Öğretmen adayına göre öğretmenlerin ders işlerken kullandığı kaynak, araç-gereç

Öğretmen adaylarına göre öğretmenlerin kullandığı araç gereçlere baktığımızda; ders kitabı ve diğer kitaplar f:52, \% 26.80, harita f:15, \% 7.73, bilgisayar f:13, \% 6.70, tepegöz f 9, \% 4.64, yazı tahtası f:9, \% 4.64, mikroskop f:7, \% 3.60, tablolar f:5, \% 2.58, öğretmenin kendi yaptı̆̆ materyaller f:4, \% 2.06, fiş f:4, \% 2.06, ansiklopedi f:4, \% 2.06, televizyon f:3, \% 1.55, resimler f:3, \% 1.55, diz üstü bilgisayar f:3, \% 1.55, teyp f:3, \% 1.55, sözlük f:3, \% 1.55, kum havuzu f:3, \% 1.55, termometre f:3, \% 1.55, yazı tahtası f:3, \% 1.55, dünya maketi f:3, \% 1.55, tebeşir f:3, \% 1.55, milli eğitimin gönderdiği set f:2, \% 1.03, fen bilgisi deney araçlan f:2, \% 1.03, mevsim şeridi f:2, \% 1.03, internet testi $\mathrm{f}: 2, \% 1.03$, tarih şeridi f:2, \% 1.03, bilgisayar çıtılar f:2, \% 1.03, deney araçları f:2, \% 1.03, bilgisayar- $\mathrm{CD}$ f:2, \% 1.03, cetvel f:2, \% 1.03, fiş kartonları $\mathrm{f}: 2, \% 1.03$, insan maketi f: $1, \%$ 0.52, televizyon -VCD f:1, \% 0.52, org f:1, \% 0.52 , matematik seti f: $1, \% 0.52$, test kitaplar f: $1, \% \quad 0.52$, atlas f: $1, \% \quad 0.52$, rakamları tanitan resimler f: $1, \%$ 0.52, kavram haritası $\mathrm{f}: 1, \% 0.52$, görsel yazı tabloları f:1, \% 0.52, Atatürk köşesi f:1, \% 0.52, video f:1, \% 0.52, plastik geometri araçları f:1, \% 0.52 olmak üzere 42 tür araç toplam (n) 194 defa işaretlenmiş. 
Yukarıdaki verilere baktığımızda öğretmen adaylarına göre öğretmenlerin kullandığı araç gereçler en çok; ders kitabı ve diğer kitaplar, harita, bilgisayar, tepegöz, yazı tahtası, mikroskop, gibi araçları en az olanlar ise; tablolar, öğretmenin kendi yaptığı materyaller, televizyon, diz üstü bilgisayar, fen bilgisi deney araçları, bilgisayar çıktılar, deney araçları, plastik geometri araçları gibi araçları kullandıklarını söyleyebiliriz. Daha çok ders kitabı, harita gibi şeyler çoğunlukla kullanılmaya devam ederken bunun yanında bilgisayar, tepegöz gibi araçlarında kullanımı artmaya başlamış diyebiliriz.

3.4.4. Öğretmen adaylarına göre birleştirilmiş sınıflarda öğretimin sorunları

- Ailelerin eğitime olumsuz bakış açısı,

- Araç gereçlerin ve fiziki koşulların yetersizliği

- Aynı anda farklı seviyelerle meşgul olma öğretmen için sorun,

- Bazı öğrencilerin hasat döneminde okula gelmemeleri,

- Bir de ödevli çalışan öğrencilerin kendi derslerinden çok öğretmenin anlattığı konuya ilgi göstermesi,

- Bireysel farklılıklar göz ardı edilmesi,

- Çalışma kitaplarındaki etkinlikler birleştirilmiş sınıflar için uygun değildir,

- Gelişim özellikleri farklı öğrencilerin bir arada olması,

- Her gruba göre çeşitli etkinlikler hazırlamak öğretmen için oldukça güç,

- Köylerde, sağlık, ulaşım ve iletişim sorunu yaşanıyor,

- Ödevli grubun kendi kendine çalışması sırasında diğer grupla birlikte ödevli grubu kontrol etmek zorlaşmıştır,

- Öğrencilere etkinlik yapabilmeleri için çok fazla zaman verilemiyor,

- Öğrencilerin seviyeleri farklı olduğu için sınıf yönetimi sorunları çıkıyor,

- Öğrencilerle pekiştirme çalışmalarının yapılamaması,

- Öğretmenin birleştirilmiş sınıflarda öğretim konusunda aldığı eğitiminin yetersiz olması,

- Öğretmenler okulda, aynı anda hem öğretmen, hem müstahdem, hem de müdür oldukları için adeta bir rol karmaşası yaşamaktadırlar, 
- Öğretmenlerin fikir alış verişi sağlayacak başka öğretmenlerin olmayışı,

- Yardımcı kaynaklara kolay ulaşabilme olanakları yetersiz olmasıdır,

- Yeni programın birleştirilmiş sınıflara göre uygun olmayışı,

- Zamanı etkin kullanma noktasında da problem yaşanmaktadır,

Yukarıdaki ifadelerden de birleştirilmiş sınıflarda; ailelerin eğitime olumsuz bakış açısı, araç gereçlerin ve fiziki koşulların yetersizliği, bireysel farklılıklar göz ardı edilmesi, köylerde, sağlık, ulaşım ve iletişim sorunu yaşanması gibi pek çok sorunun yaşanmaya devam ettiğini söyleyebiliriz.

3.4.5. Öğretmen adaylarına göre birleștirilmiş sınıflardaki öğretimin

\section{faydaları}

- Alt sınıflara anlatım yapılırken üst sınıflar geçmiş bilgilerini tekrar etme fırsatı bulabilmektedir,

- Birleştirilmiş sınıfların en önemli faydası farklı grup, seviye, üst sınıftaki bir öğrencinin alt sınıftaki öğrenciye rehberlik etmesidir,

- Birlikte bulunmaları sevgi saygı paylaşma gibi özellikleri kazanmalarına yardımcı oluyordu, öğrencilerin birbirleriyle olan etkileşimleri artmakta, üst sınıftaki öğrencilerin alt sınıftaki öğrencilere yardım etmektedir,

- Bu okullar sayesinde eğitim ve öğretim her bölgeye ulaştırılır,

- Ekonomik yönden devlet bütçesine önemli katkısı bulunmaktadır,

- Etkileşimleri sonucu sosyal becerileri güçlenir, bazı çocukların liderlik özelliklerini geliştiriyor,

- Liderlik, sorumluluk alma ve grubun parçası olduğunu hissetme duygular gelişir,

- Ödevlerini kendi başlarına yaparken bireysel çalışma imkânı buluyorlar,

- Öğrencilerde arkadaşlık bağları güçlenir,

- Öğrencileri kırmadan seviye grubu oluşturulabilir,

- Öğrencilerin bir üst sınıftaki konularla ilgili ön bilgi edinmesini, üst sınıftaki öğrencilerinde önceki yıllarda unuttukları bilgileri hatırlamasını sağlar, 
- Öğrencilerin farklı yaş, bilgi ve deneyim düzeyindeki öğrencilerin bir arada olması gibi faydası vardır, birleriyle etkileşme ve birbirlerine yardımlaşma,

- Öğretmen diğer sınıfla ders işlerken kendi başlarına ders yapabilmekte, birbirlerine soru sorabilmekte, tartışabilmekte, yardımlaşma ve paylaşım davranışları giderek artıyor,

- Ülke öğretmen ihtiyacının karşılamasına katkıda bulunmasıdır,

Öğretmen adayları genel olarak etkileşim, yardımlaşma ve kaynaşma büyüklerden öğrenme vb. gibi açılardan birleştirilmiş sınıf uygulamasının faydalı olduğunu söylüyorlar.

\subsection{6. Öğretmen adaylarına göre birleştirilmiş sınıflardaki öğretimin} sakıncaları

- Araç-gereç yetersizliğinden eğitim ve öğretim akması,

- Bir sınıfa ders anlatırken diğer sınıfın kendi derslerine çalışma yerine öğretmeni dinlemesi problem oluyor,

- Birleştirilmiş sınıflar konusunda yeterli bilgi düzeyine sahip olmayan öğretmenlerin öğretim yapması,

- Birleştirilmiş sınıflarda en büyük sorun, öğretmensiz geçen sınıfları kendi kendilerine çalıştırabilmektir, bu sınıflarda sessiz çalışma saatleri olduğu için öğrenciler daha az aktif durumdalar,

- Burada okuyan öğrencilerin kendilerine güvenleri az, öğretmenler ise zoraki zaman geçirme eğilimindedirler,

- Eğitim ve öğretimde verimlilik tam olarak sağlanamamaktadır, gürültü çok fazla olduğu için ders verimli geçmiyor,

- En önemli sorun programların yetişmemesidir,

- İlköğretimin tüm hedeflerine ulaşmak güçleşiyor,

- Öğrencilerin birden fazla grubun bir arada olmasından dolayı dikkatlerini toplamak ve devam ettirmenin zor olmasi

- Öğretmen özel ihtiyacı olan öğrencilere zaman ayıramıyor,

- Öğretmensiz geçen derslerde öğrenciler kendi derslerine motive olamiyorlar, 
- Yeni eğitim sisteminin gerektirdiği etkinlikli öğretimi bu sınıflarda yapmak nerdeyse imkânsızdır,

- Yeni mezun bir öğretmenin hemen birleştirilmiş sınıflarda öğretim yapmaya başlaması başlıca sakıncadır,

- Yeni program birleştirilmiş sınıflara uygun değil,

Öğretmen adaylarına göre; bu uygulama hakkında yetersiz öğretmenlerin olması, ödevli saatlerde öğrenciyi aktif kılmanın zor olması, bu uygulama içindeki öğrencilerin kendilerine güvenleri az olması, ilköğretimin tüm hedeflerine ulaşmanın zorlaşması gibi sakıncaları olduğu ifade edilmiş.

\subsection{7. Öğretmen adaylarının birleştirilmiş sınıflardaki sorunlara çözüm önerileri}

- Araç- gereç yetersizliği giderilmeli,

- Birleştirilmiş sınıflara uygun müfredat ve kaynak kitaplar hazırlanmalıdır,

- Birleştirilmiş sınıflarda öğretim yapan öğretmenlerin tecrübeli olması, yaşam koşulları iyileştirilmeli ve öğretmenler bu konuda daha iyi donanımlı olmalı,

- Birleştirilmiş sınıfları ortadan kaldırmak ve öğrencileri yatılı bölge okullarına göndermek ya da taşımalı sisteme geçmek,

- En iyi çözüm ise bu sistemi tamamen kaldırıp taşımalı eğitime geçmelidir,

- Etkinlikler ve projeler köy yaşamının da göz önüne alarak seçilmelidir,

- Okul aile ile işbirliği içerisinde olmalıdır,

- Öğrencilerin kendi kendine çalışma saatlerinde yararlanabilecekleri kaynak sayısı arttırılmalı,

- Öğretim etkinlikleri birleştirilmiş sınıflara da uygun bir şekilde hazırlanabilir,

- Öğretmen adaylarını staj için son dönem köylere göndermeliler,

- Öğretmen kılavuz kitaplarına ve ders kitaplarına köyde yaşayan ve köy şartlarına uygun proje ve araştırma çalışmaları konmalı,

- Öğretmen yetiştiren fakültelerde birleştirilmiş sınıf eğitimine gereken önemin (bir dönemlik bir ders değil daha fazla) verilmeli, 
- Özellikle öğretmensiz derslerde öğrencilerin önceden yapacakları çalışmaları bilmesi bu sorunu aşmada en önemli rol olacaktır,

- Programlar hazırlanırken birleştirilmiş sınıfları da göz önüne alarak hazırlanmalıdır,

İfadelerden de anlaşılıyor ki; araç-gereç yetersizliğinin giderilmesi, birleştirilmiş sınıflara uygun program ve kaynak kitapların hazırlanması, görev yapacak öğretmenlerin tecrübeli ve gerekli eğitimi almış olması, öğrencileri yatılı bölge okullarına göndermek ya da taşımalı sisteme geçmek, öğretmen adaylarını staj için son dönem köylere göndermeliler, gibi çözüm önerileri verilmiş.

\subsection{Birleştirilmiş sınıflarda görev yapan öğretmen ile bu sınıflarda} gözlem ve uygulama yapan öğretmen adaylarının görüş̧lerinin karşılaştırılması

Öğretmen ve öğretmen adaylarına göre birleştirilmiş sınıflarda öğretim yapan öğretmenlerin en çok kullandığı yöntemler; anlatım ve soru cevap yöntemidir. Yine öğretmenlere ve öğretmen adaylarına göre araştırma-inceleme, deney, eğitsel oyunlar, proje çalışması, büyüklerin rehberliği, gösteri, seviye grupları, bireysel çalışma yöntemi, gezi-gözlem bilgisayar destekli öğretim, rol yapma, küme çalışması, örnek olay gibi yöntemler en az kullanılan yöntemler arasında yer almaktadır. Özellikle birleştirilmiş sınıf öğretimi yapan öğretmenlerin birleştirilmiş sınıflarda öğretim alanının kendi özelliğinden dolayı bu alanda kullanılan; küme çalışması, büyüklerin rehberliği, seviye grupları ve bireysel çalışma yöntemi gibi yöntemlerinde hem öğretmenler hem öğretmen adayları tarafından az kullanıldığı belirtilmiştir.

Öğretmen ve öğretmen adaylarına göre birleştirilmiş sınıflarda öğretim yapan öğretmenlerin kullandığ 1 araç-gereçler içersinde en çok ders kitabı, tepegöz, bilgisayar kullanıldığı en az ise bilgisayar çıktıları, fen dolabı, fotokopi, tablolar, öğretmenin kendi yaptığı materyaller, deney araçları gibi araçları kullanılmaktadır.

Öğretmen ve öğretmen adaylarına göre birleştirilmiş sınıflarda öğretim yapan öğretmenlerin sorunları; öğrencilere bireysel ilgi verilemiyor, veliler ilgisiz, zaman yetmiyor, hedeflere tam ulaşılamıyor, zamanın yetmemesi, araç 
gereç yetersizliği, fiziki koşulların yetersizliği gibi pek çok sorunun yaşanmaya devam ettiğini söyleniyor.

Öğretmen ve öğretmen adaylarına göre birleştirilmiş sınıflarda öğretim yardımlaşma paylaşma ve öğrencilerin sosyalleşmesi ve büyüklerden öğrenme gibi faydaları olduğu belirtilmiş.

Öğretmen ve öğretmen adaylarına göre birleştirilmiş sınıflarda öğretim zamanın yetmemesine, bireysel farkların dikkate alınamaması, yeterli eğitimi almamış ve meslekte yeni öğretmenler, öğrencilerin birden fazla grubun bir arda olmasından dolaysı dikkatlerini toplamanın zor olduğu gibi sıkıntılar belirtilmiş

Öğretmen ve öğretmen adaylarına göre birleştirilmiş sınıflarda öğretimin daha iyi olması için; taşımalı ilköğretim, yatılı bölge ilköğretim okulu gibi uygulamalarla bu uygulamanın azaltılması, öğretmenin durumunun ekonomik ve sosyal olarak iyileştirilmesiyle, programın ve ilgili etkinliklerin bu uygulamaya göre düzenlenmesiyle, görev alacak öğretmenlerin hizmet öncesinde stajla hizmet içinde kurslarla eğitilmesi, öğretmene ek kaynaklar sağlanması vb ile çözülebileceği belirtilmişlerdir. Genel olarak öğretmen ve öğretmen adaylarının birleştirilmiş sınıflardaki öğretime ilişkin görüşlerinde benzer sonuçların olduğunu söyleyebiliriz.

\section{Sonuç}

Birleştirilmiş sınıf öğretimi yapan öğretmenlerin kendi belirtiklerine göre; ağırlıklı olarak geleneksel öğretim yöntemlerini kullanmaya devam ettikleri, ayrıca birleştirilmiş sınıflarda öğretimde kullanılan; küme çalışması, büyüklerin rehberliği, seviye grupları ve bireysel çalışma yöntemi gibi yöntemlerinde en az kullanılan yöntemler arasında olduğu söylenebilir. Öğretmenlerin kullandığı araç-gereçler içersinde en çok ders kitabı, tepegöz, bilgisayar, gibi araçlar olduğu, birleştirilmiş sınıflarda öğretim konusundaki sorunların; öğrencilere bireysel ilgi gösterilemiyor, veliler ilgisiz, zaman yetmiyor, hedeflere tam ulaşılamıyor. Ayrıca öğretmenler bu uygulama biçiminin daha çok yardımlaşma paylaşma ve öğrencilerin sosyalleşmesini artırması açısından faydalı olduğunu belirtmişler.

$\mathrm{Bu}$ uygulamamın sakıncalarını; zamanın yetersiz kalması, büyüklerin küçükler üzerinde hâkimiyet kurması, tekrar ve pekiştirmenin yapılamaması, ödevli grubun dikkat eksikliğinden gerekli verimin alınamaması gibi noktalarda 
yoğunlaştığını, çözümün; bu uygulamanın mümkün olduğunca kaldırılmasıyla, programın ve etkinliklerin bu uygulamaya göre düzenlenmesiyle olacağını ifade etmişlerdir.

Öğretmen adaylarının belirttiğine göre toplam uygulamaya gidilen 20 okulda altı farklı birleştirilmiş sınıf uygulamasının var olduğu, öğrenci sayısı açısından okulların aşırı değişkenlik gösterdiği söylenebilir. Bu yirmi okulda birleştirilmiş sınıf kutan öğretmen bir veya iki kişidir. Genel olarak bu okullarda velilerin ilgisizliği, ısınma, ulaşım ve temizlik vs alanlarda hala sorunlar yaşanmaya devam ettiğini öğretmen adaylarının ifadelerinden anliyoruz.

Öğretmen adayları da birleştirilmiş sınıf öğretimi yapan öğretmenlerin genel olarak geleneksel öğretim yöntemlerini kullanmaya devam ettiğini ve bu alanda kullanılan; küme çalışması, büyüklerin rehberliği, seviye grupları gibi yöntemlerin en az kullanılan yöntemler arasında olduğu ifade etmektedirler. Araç olarak ders kitabı, harita gibi şeyler çoğunlukla kullanılmaya devam ederken bunun yanında bilgisayar, tepegöz gibi araçlarında kullanımı da artmaya başlamış diyebiliriz. Birleştirilmiş sınıflarda; ailelerin eğitime olumsuz bakış açısı, araç gereçlerin ve fiziki koşulların yetersizliği, gelişim özellikleri farklı öğrencilerin bir arada olması, köylerde, sağlık, ulaşım ve iletişim sorunlarının yaşanması gibi pek çok sorunun devam ettiğini, bu uygulamanın etkileşim, yardımlaşma ve kaynaşma büyüklerden öğrenme vb. gibi açılardan faydalı olduğunu, ayrıca öğretmen adaylarına göre; bu uygulama hakkında yetersiz öğretmenlerin olması, bu uygulama içindeki öğrencilerin kendilerine güvenleri az olması, ilköğretimin tüm hedeflerine ulaşmanın zorlaşması gibi sakıncaları olduğunu belirtmişlerdir. Çözümün ise araç-gereç yetersizliği giderilmesi, birleştirilmiş sınıflara uygun program hazırlanması, görev yapacak öğretmenlerin tecrübeli ve gerekli eğitimi almış olması, öğrencileri yatılı bölge okullarına göndermek ya da taşımalı sisteme geçmek, öğretmen adaylarını staj için son dönem köylere göndermelileri gibi noktalarda gördüklerini söyleyebiliriz.

Çınarın (2004) araştırmasında; eğitim fakültelerinin sınıf öğretmenliği programlarında bulunan iki kredilik "birleştirilmiş sınıflarda öğretim" dersinin köy okullarında uygulamalı olarak yapılmasının sağlanması, hem öğretmen 
adaylarının köy yaşamını tanımaları hem de birleştirilmiş sınıflarda öğretmenlik yapma becerilerini geliştireceği belirtilmektedir. $\mathrm{Bu}$ belirleme bizim araştırmamızın sonuçlarıyla da örtüşmektedir.

Sonuç olarak; birleştirilmiş sınıflarda öğretmen olmak, müstakil sınıflarda öğretmen olmaya oranla daha ayrı bir yetenek, bilgi ve tecrübe ve gayret gerektirmektedir diyebiliriz. Ancak incelediğimizde milli eğitim bakanlığının hizmet içi planlarında birleştirilmiş sınıflarda öğretime yönelik bir kurs yok, eğitim fakültelerinde bu dersi okutan ögretim elemanlarının da tam olarak bu alanla ilgili olduklanı ve bu alanda çalışma yaptıklanı ve bu dersin öğretimini etkili yaptıkları söylenemez. Bu nedenle sınıf öğretmeni yetiştiren programa bu alanla ilgili dersi okutacak öğretim elamanının bu alanda eğitim alması, öğretmen adayının bu alanla ilgili eğitim alması ve uygulama(staj) yapması gerekmektedir. Çünkü öğretmen adayları hizmet öncesi uygulama eğitimlerini (öğretmenlik uygulaması) dersini birleştirilmiş sınıf uygulaması olan yerde yapmamakta ama ilk ataması genelde bu tür bir sınıfa olabilmektedir. Sınıf öğretmeni olacak öğretmen adaylarının öğretmenlik uygulamasının (staj) bir kısmını köylerde yapmaları sağlanmalıdır.

Birleştirilmiş sınıflarda eğitim-öğretim etkinliklerini yerine getirirken öğretmenler normal müstakil sınıflara göre daha fazla çaba harcamaktadır. Buradan hareketle bu uygulamada görev alan öğretmenlere bakanlık yeni bir düzenlemeyle ilave bir ödenek veya ders ücreti gibi uygulama yapması bu durumunda öğretmenlerin motivasyonlarını artıracak ve bu uygulama da isteyerek görev alacaklardır.

\section{Kaynaklar}

Akpınar, B., Turan, M. \& Gözler, A. (2006) "Birleştirilmiş Sınıflarda Görev Yapan Öğretmenlerin Yeni İlköğretim Müfredatına İlişkin Görüş ve Önerileri” Ulusal Sınıf Öğretmenliği Kongresi, (Gazi Üniversitesi Gazi Eğitim Fakültesi 14-16/Nisan/2006, Ankara) Bildiri Kitabı 2. Cilt, 403414, Kök Yayıncılık, Ankara. 
Dursun, F./ Sosyal Bilimler Araştırmaları Dergisi. 2, (2006):33-57

Çınar, İ. (2004). "Birleştirilmiş Sınıflı İlköğretim Okullarında İlk okuma Yazma Öğretimine İlişkin Bir Araştırma” İnönü Üniversitesi Eğitim Fakültesi Dergisi Cilt:5, Sayı:7, 31-45.

Dalka, S. (2006 ) “ Birleştirilmiş Sınıflı Köy Okullarının Problemleri ve Durum Tespiti: Doğu Beyazıt Örneği” Ulusal Sınıf Öğretmenliği Kongresi, (Gazi Üniversitesi Gazi Eğitim Fakültesi 14-16/Nisan/2006, Ankara), Bildiri Kitabı 2. Cilt, 415-420, Kök Yayıncılık, Ankara.

Eğitimsen (2006) "Yeni İlköğretim Müfredatının Değerlendirilmesi”, Online: http://www.egitimsen.org.tr/index.php?yazi=38, (19-05-2006

Erdem, A. R. (2004) Birleştirilmiş Sinıflarda Öğretim. Anı Yayıncılık, Ankara.

Erdem, A. R., Kamacı, S. \& Aydemir, T. (2005). "Birleştirilmiş Sınıfları Okutan Öğretmenlerin Karşılaştıkları Sorunlar” Denizli Örneği. Eğitimde Kuram ve Uygulama, 1 (1-2): 3-13.

Fidan, N. \& Baykul, Y. (1993). Birleştirilmiş Sinıflarda Öğretim Öğretmen Rehberi. Milli Eğitim Bakanlığı ve Unicef Türkiye Temsilciliği, Ankara.

Gültekin, M. \& Karadağ, R. (2005) "İlköğretimde Birleştirilmiş Sınıflar, Taşımalı Eğitim Ve Yatılı İlköğretim Bölge Okulu Uygulamalarına Yönelik Araştırma Sonuçlarının Analizi” XIV. Ulusal Eğitim Bilimleri Kongresi- Pamukkale Üniversitesi Eğitim Fakültesi 28-30 Eylül 2005 Denizli) Kongre Kitabı Cilt:2, 79-64, Anı Yayıncılık, Ankara

Kılınç, S. (2005) "Birleştirilmiş ve Normal Sınıflarda Okuyan 4. ve 5. Sınıf Öğrencilerinin Türkçe ve Matematik Derslerindeki Başarılarının Karşılaştırılması",Online:http://sbe.gantep.edu.tr/Tez\%20Ozetleri/Egitim \%20Bilimleri/Yuksek\%20Lisans/Kilic\%20Selcuk.htm, 10-08-2006

Köksal, K. (2005). Birleştirilmiş sinıflarda Öğretim. PegemA Yayıncılık, Ankara. 
Dursun, F./ Sosyal Bilimler Araştırmaları Dergisi. 2, (2006):33-57

MEB (2005) “2004-2005 Yılı Sayısal Verileri”, Online: http://apk.meb.gov.tr(15-08-2006)

Radikal Gazetesi ( 2005) “Birleștirilmiș Sınıflara Çare Yok-(04.01.2005)”, s.5.

Şahin, A. E. (2003) "Birleştirilmiş Sınıflar Uygulamasına İlişkin Öğretmen Görüşleri” Hacettepe Üniversitesi Eğitim Fakültesi Dergisi, 25, 166175 